Rabeler Richard ～K. (Orcid ID: 0000-0002-6765-0353)

Kovalchuk Andriy (Orcid ID: 0000-0001-8704-4644)

[Article Category: SYSTEMATICS AND PHYLOGENY]

[Running Header:] Pirani \& al. • Phylogeny of Acanthophyllum s.l. revisited

Article history: Received: 5 Sep 2019 | returned for (first) revision: 23 Jan 2020 | (last) revision received: 6 Mar 2020 | accepted: 19 Mar 2020

Associate Editor: M. Montserrat Martinez-Ortega | ( 2020 International Association for Plant Taxonomy

\title{
Phylogeny of Acanthophyllum s.l. revisited: An update on generic concept and sectional classification
}

\author{
Atefeh Pirani, ${ }^{1,2}$ Hamid Moazzeni, ${ }^{2}$ Shahin Zarre, ${ }^{3}$ Richard K. Rabeler, ${ }^{4}$ Bengt Oxelman, ${ }^{5}$ Alexander V. Pavlenko ${ }^{6}$ \& \\ Andriy Kovalchuk ${ }^{7,8}$
}

1 Department of Biology, Faculty of Science, Ferdowsi University of Mashhad, P.O. Box 91775-1436, Mashhad, Iran

2 Herbarium FUMH, Department of Botany, Research Center for Plant Sciences, Ferdowsi University of Mashhad, P.O. Box 91775-1436, Mashhad, Iran

3 Department of Plant Biology, and Center of Excellence in Phylogeny of Living Organisms, School of Biology, College of Science, University of Tehran, P.O. Box 14155-6455, Tehran, Iran

4 University of Michigan Herbarium - EEB, 3600 Varsity Drive, Ann Arbor, Michigan 48108-2228, U.S.A.

5 Department of Biological and Environmental Sciences, University of Gothenburg, Box 461, 40530 Göteborg, Sweden

6 Institute of Biology and Medicinal Plants, Academy of Sciences of Turkmenistan, Ashgabat, Turkmenistan

7 Department of Forest Sciences, P.O. Box 27, University of Helsinki, 00014 Helsinki, Finland

8 Present address: VTT Technical Research Centre of Finland Ltd, Tietotie 2, 02044 Espoo, Finland

Address for correspondence: Atefeh Pirani, apirani@um.ac.ir

\begin{abstract}
The generic boundary of the broadly defined Acanthophyllum s.l., the third-largest genus of the tribe Caryophylleae (Caryophyllaceae), has been a subject of taxonomic confusion. Acanthophyllum s.l. now includes five minor genera previously recognized as independent. Among these small genera, the inclusion of Allochrusa, Ochotonophila, and Scleranthopsis within Acanthophyllum s.l. was confirmed by previous molecular studies, while the positions of Diaphanoptera and Kuhitangia remained uncertain. We have performed an updated molecular study of Acanthophyllum s.l. including an increased sampling of the genera and sections assigned to this group, using intron sequences of the chloroplast gene rps16 and nuclear ribosomal internal transcribed spacer (ITS) sequences. Cyathophylla, Heterochroa, and Saponaria were chosen as outgroups for performing phylogenetic analyses using maximum likelihood and Bayesian methods. The present results suggest that, in addition to the genera mentioned above, both Diaphanoptera and Kuhitangia should also be synonymized within Acanthophyllum. Sections Diaphanoptera, Kuhitangia and Pseudomacrostegia are introduced as new infrageneric taxa within Acanthophyllum. Our results also indicate that some annual species of Saponaria are closely related to Acanthophyllum.
\end{abstract}

Keywords annual Saponaria; Caryophylleae; Diaphanoptera; Irano-Turanian; Kuhitangia; sect. Macrostegia

This is the author manuscript accepted for publication and has undergone full peer review but has not been through the copyediting, typesetting, pagination and proofreading process, which may lead to differences between this version and the Version of Record. Please cite this article as doi: $10.1002 / \operatorname{tax} .12241$ 


\section{INTRODUCTION}

The genus Acanthophyllum C.A.Mey. s.l. (referred to hereafter as "Acanthophyllum") is one of the larger genera of the Caryophyllaceae Juss., comprising 90-100 species distributed in the Irano-Turanian region. It belongs to the tribe Caryophylleae Lam. \& DC. and represents the third-largest genus of the tribe, after Dianthus L. (about 300 species, see e.g., Valente \& al., 2010; Hernández-Ledesma \& al., 2015) and Gypsophila L. (about 150 species, see, e.g., Hernández-Ledesma \& al., 2015; Madhani \& al., 2018). Acanthophyllum species are perennial subshrubs, predominantly forming cushions with spiny leaves (see, e.g., Bittrich, 1993, and Pirani \& al., 2014) (Fig. 1). In the broad sense, the genus would include the following five minor genera that were previously treated as separate: Allochrusa Bunge ex Boiss., Diaphanoptera Rech.f., Kuhitangia Ovcz., Ochotonophila Gilli, and Scleranthopsis Rech.f. (Pirani \& al., 2014). The inclusion of Allochrusa, Ochotonophila, and Scleranthopsis within Acanthophyllum has been recently confirmed by Pirani \& al. (2014), while the types of Diaphanoptera and Kuhitangia have not been investigated from the molecular point of view. A recent molecular study of the tribe Caryophylleae revealed that a few taxa from Gypsophila should also be included in Acanthophyllum (Madhani \& al., 2018).

Kuhitangia is a small and barely known genus of perennial, cushion-forming subshrubs, which is distributed in Central Asia and includes two species, i.e., K. popovii (Preobr.) Ovcz. (the type of the genus according to Ovczinnikov, 1967) and K. knorringiana (Schischk.) Bondarenko. Before being transferred to Kuhitangia, both species were variously treated either as Acanthophyllum or as Gypsophila by different authors (Schischkin, 1936; Barkoudah, 1962; Ovczinnikov, 1967, 1968). When establishing the genus Kuhitangia, Ovczinnikov (1967) compared it with Acanthophyllum, Gypsophila, Kohlrauschia Kunth, and Petrorhagia (Ser.) Link. Kuhitangia was morphologically differentiated from Acanthophyllum mainly based on the long peduncles that much exceed the cushion, small petals that lack a claw, and many-seeded capsules opening by four teeth (Ovczinnikov 1967, 1968). Some authors (e.g., Bittrich, 1993, and Hernández-Ledesma \& al., 2015) treated Kuhitangia as a synonym of Acanthophyllum, while others (e.g., Takhtajan, 2009) recognized the genus as independent.

Diaphanoptera was originally described from Iran with the single species $D$. khorasanica Rech.f. (Rechinger, 1940). It is a small Irano-Turanian genus of six species of multi-stemmed subshrubs distributed in Afghanistan, Iran, and Turkmenistan. It is morphologically similar to Acanthophyllum, from which it can be distinguished by diaphanous (translucent) wings on the calyx as well as non-spiny leaves (see Rechinger, 1940) (Fig. 1I-L). Diaphanoptera species are mainly local endemics or occur in restricted distribution areas (Schiman-Czeika, 1988; Kiani \& al., 2013). Four of the six species have been sampled in recent phylogenetic studies of Caryophyllaceae. Pirani \& al. (2014) revealed that Diaphanoptera in its traditional concept is not monophyletic and includes at least two phylogenetically distinct groups. However, $D$. khorasanica, the type of the genus, was not included in that study, rendering the phylogenetic position of the genus unresolved.

Allochrusa, in the traditional sense, is a small genus of ca. eight subshrubby perennial species distributed in NW Iran, Turkey and Transcaucasia (Mahmoodi \& Nejad Falatoury, 2016). Possessing enclosed stamens and non-spiny leaves (Fig. 1F-H), Allochrusa was considered as distinct from Acanthophyllum (Bunge, 1867). However, some authors reduced Allochrusa to an infrageneric taxon within Acanthophyllum (e.g., Golenkin, 1893; Schischkin, 1936). Pirani \& al. (2014) sampled three Allochrusa species (including the type, Al. versicolor (Fisch. \& C.A.Mey.) Boiss.), and the inclusion of Allochrusa in Acanthophyllum was confirmed.

The results of the most comprehensive molecular study of the tribe Caryophylleae (Madhani \& al., 2018) indicated that the traditional boundaries of Saponaria L. need to be reassessed, as the annual S. viscosa C.A.Mey. did not group with the monophyletic clade holding biennial and perennial species of the genus. Instead, S. viscosa together with Cyathophylla chlorifolia (Poir.) Bocquet \& Strid, formed a clade closely related to Acanthophyllum, raising a question about the phylogenetic position of the annual species of Saponaria.

Regarding the infrageneric classification of Acanthophyllum, Pirani \& al. (2014) showed that the 11 sections are generally monophyletic, or rendered as monophyletic after a few species are removed. Among the surveyed sections are sect. Macrostegia (Boiss.) Pax and sect. Oligosperma Schischk. ex Schiman-Czeika, two groups with considerable internal 
morphological heterogeneity. Section Macrostegia includes taxa with both spiny (e.g., A. bracteatum Boiss.), and non-spiny (e.g., A. korolkowii Regel \& Schmalh., A. coloratum Schischk.) leaves. Non-spiny members of the section have not been included in previous molecular investigations, and their phylogenetic relationship with the spiny ones has not been investigated. The other morphologically diverse group, sect. Oligosperma, is the largest (ca. 30 species) and most widespread section of the genus, whose members can be found from NW Iran to W China. Morphological characters used for separating species of sect. Oligosperma are confusing, and a few species of the section have overlapping features. This taxonomic complexity was reflected in the previous study of the group (Pirani \& al., 2014), in which internal relationships within the section were not satisfactorily resolved using ITS and rps16 data. The latter study concluded that a more extensive sampling of the section might help resolve the species.

Principal aims of the present study are: (1) to test the phylogenetic position of Kuhitangia using molecular data, (2) to further investigate the phylogenetic status of Diaphanoptera and Allochrusa using expanded taxon sampling, and (3) to reassess monophyly of Acanthophyllum sect. Macrostegia and sect. Oligosperma using more inclusive sets of taxa.

\section{MATERIALS AND METHODS}

Taxon sampling. - We have sampled all currently recognized taxa of Acanthophyllum s.l. represented in previous studies, as well as 38 DNA sequences that were generated in this study, including 19 nuclear ribosomal internal transcribed spacer (ITS) and 19 rps16. The new sequences correspond to three accessions assigned to A. sect. Macrostegia, five accessions assigned to $A$. sect. Oligosperma, three accessions assigned to $A$. sect. Paniculata Golenk., two accessions assigned to Allochrusa, three accessions assigned to Kuhitangia, two accessions assigned to Diaphanoptera, and one annual Saponaria species.

Heterochroa desertorum Bunge, H. violacea (Ledeb.) Walp., Yazdana shirkuhensis A.Pirani \& Noroozi, and Cyathophylla viscosa (C.A.Mey.) Madhani \& Rabeler served as outgroup taxa (Madhani \& al., 2018; Noroozi \& al., 2020). Voucher information and GenBank accession numbers for all included specimens are listed in Appendix 1.

Typification information. - Details about type specimens of the basionyms of the new combinations included here are based on examining protologues and searching major indices (Tropicos - http://www.tropicos.org/; JSTOR Global Plants - https://plants.jstor.org; GBIF - http://gbif.org), as well as websites of individual herbaria (BM, E, G, K, WU) for extant specimens. We have examined a digital image from at least one of these sources for any specimen with a cited barcode.

DNA extraction, amplification, and sequencing. - Total genomic DNA was extracted from herbarium materials, deposited at FUMH, H, LE, TARI, TASH, and TK, using the DNeasy Plant Mini kit (Qiagen; Germantown, Maryland, U.S.A.) according to the manufacturer's protocol, or the $2 \times$ cetyltrimethylammonium bromide (CTAB) extraction protocol (Doyle \& Doyle, 1987). The nuclear ribosomal internal transcribed spacer (ITS) region and the complete intron of the plastid rps16 gene were amplified using primers P17/26S-82R and rpsF/rpsR2R, respectively (Oxelman \& al., 1997; Popp \& Oxelman, 2001). Amplification products were purified using PEG (Joly \& al., 2006), or the GenElute PCR Clean-Up kit for PCR product purification (Sigma Aldrich; Saint Louis, Missouri, U.S.A.) according to the manufacturer's instructions. Sequencing was performed by Macrogen (Seoul, South Korea and Amsterdam, The Netherlands) using PCR primers P16S/ITS4 (Eggens \& al., 2007; Popp \& Oxelman, 2007) and rpsF2a/rpsR3R (Popp \& al., 2005) for ITS and rps16, respectively. Sequences were trimmed, assembled and aligned using Geneious v.6.1.2 (https://www.geneious.com). The MUSCLE Plug-in was used with the default setting. The best substitution model for each alignment was selected using jModelTest v.2.1.4 (Darriba \& al., 2012). The GTR $+\Gamma+\mathrm{I}$ and GTR $+\Gamma$ models were determined as the best-fit models for nuclear and chloroplast markers, respectively. The alignments for both the ITS and the rps16 datasets are available as supplementary Appendices S1 and S2, respectively.

Phylogenetic analyses. — Phylogenetic analyses were performed using maximum likelihood (ML) and Bayesian 
inference (BI). The ML analysis was carried out using the IQ-TREE web server (http://iqtree.cibiv.univie.ac.at/) using 1000 bootstrap replicates, obtained by the ultrafast bootstrap approximation (UFBoot) (Minh \& al., 2013). Bayesian inference (BI) of the individual gene analyses was performed using MrBayes v.3.1.2 (Huelsenbeck \& Ronquist, 2001) at the CIPRES portal (http://www.phylo.org/index.php/portal/) with default prior settings, for 20 million MCMC generations. The quality of the analysis was checked by comparing likelihood values and parameter estimates from different runs in Tracer v.1.6 (http://tree.bio.ed.ac.uk/software/tracer/), and $25 \%$ of the trees were discarded as burn-in. The remaining trees were summarized in a 50\% majority-rule consensus tree.

Construction of the secondary structure of ITS1 sequence. - Although Pirani \& al. (2014) showed that Acanthophyllum s.l. is a monophyletic clade, placement of Diaphanoptera afghanica (accession number KF924632) outside of this clade raised the question of the possible polyphyly of Diaphanoptera. The ITS sequence obtained from type material (Podlech 21075 [MSB]) and a BLAST search did not show any fungal or algal contamination. Moreover, analysis of two ITS sequences of Saponaria kermanensis (accession numbers KX184037 and KX184038, obtained from GenBank), along with the sequences from the tribe Caryophylleae available in GenBank and the present study, showed a different position for these two accessions (data not shown). The mean divergence value between the KX184037 and the KX184038 sequences is 8\%, and based on a phylogenetic analysis, the $S$. kermanensis under accession no. KX184037 fell within Acanthophyllum close to S. makranica, while the divergent ITS allele (KX184038) was placed outside of Acanthophyllum. Therefore, to be sure about orthology of these sequences, we reconstructed the secondary structure of ITS1 to find the highly conserved motif (Liu \& Schardl, 1994; GGCRY-(4 to 7n)-GYGYCAAGGAA) in ITS1. The ITS1 of $D$. afghanica and both mentioned S. kermanensis taxa were folded using the Mfold program at $37^{\circ} \mathrm{C}$ (folding at $10^{\circ} \mathrm{C}$ and $20^{\circ} \mathrm{C}$ resulted in identical structures), hosted at the M. Zuker web server (http://mfold.rna.albany.edu/?q=mfold).

\section{RESULTS}

Phylogenetic analyses. - Trees yielded by ML and BI analyses of individual plastid and nuclear markers were mostly congruent within each marker. Therefore, only the results of BI analyses are presented and discussed here, and those of ML analyses are summarized in Fig. 2.

Members of both datasets resolved within two main well-supported clades, clades 1 and 2, in both the ITS and the rps16 tree (Fig. 2). Phylogenetic positions of the taxa treated in the present survey are summarized below.

Diaphanoptera khorasanica and D. transhyrcana (Preobr.) Rech.f. \& Schiman-Czeika comprise a monophyletic clade together with $D$. lindbergii Hedge \&Wendelbo and D. stenocalycina Rech.f. \& Schiman-Czeika, which is strongly supported on both the ITS (PP 0.99) and the rps16 (PP 1) tree.

Kuhitangia popovii and the two individuals of $K$. knorringiana nest in a monophyletic clade with strong support (PP 0.97) in the ITS tree, while they appear within an unresolved polytomy in the rps16 tree (Fig. 2).

Allochrusa lutea Falat. \& Mahmoodi, Al. persica Boiss., Al. versicolor, and Al. bungei Boiss. form a monophyletic clade with strong support (PP 1) in the ITS tree (Fig. 2). Monophyly of these taxa is not obtained in the rps16 tree, where Al. lutea and Al. persica fall out of the core group of Acanthophyllum sect. Allochrusa (Bunge ex Boiss.) A.Pirani \& Rabeler (Fig. 2). Allochrusa gypsophiloides (Regel) Schischk. and Al. paniculata (Regel \& Herder) Ovcz. \& Czukav. resolve as a monophyletic clade in the ITS tree, while Al. tadshikistanica Schischk. does not group with any of the Allochrusa species (Fig. 2). On the rps16 tree, Al. gypsophiloides and Al. tadshikistanica do not form a monophyletic clade and reside in different groups (Fig. 2).

Saponaria kermanensis and S. makranica Rech.f. form a monophyletic clade within Acanthophyllum in the ITS tree (Fig. 2). Although our survey lacks an rps16 sequence for S. kermanensis, S. makranica nests within Acanthophyllum in the rps16 tree (Fig. 2). 
Our analyses showed that Acanthophyllum coloratum, A. korolkowii, and A. sarawschanicum Golenk. do not fall within the core group of sect. Macrostegia. In the ITS tree they resolve as a monophyletic clade (with low support; PP 0.7) together with A. aphananthum Rech.f. and Allochrusa tadshikistanica (Fig. 2). In the rps16 tree, A. coloratum and A. sarawschanicum make a strongly supported clade (PP 0.97) together with Al. tadshikistanica, while A. korolkowii shows a remote relationship to this clade (Fig. 2).

All of the four newly examined species of sect. Oligosperma (Acanthophyllum aculeatum Schischk., A. elatius Bunge, A. pulchrum Schischk., A. pungens Boiss.) reside within the monophyletic clade including the rest of the section in the ITS tree (Fig. 2). However, A. pulchrum does not group within sect. Oligosperma in the rps16 tree (Fig. 2).

Construction of the secondary structure of ITS1. - The highly conserved motif (Liu \& Schardl, 1994) in ITS1 for Diaphanoptera afghanica (see Fig. 3) and Saponaria kermanensis (KX184038) does not form a hairpin structure (data not shown), which means these divergent ITS alleles are non-functional paralogues.

\section{DISCUSSION}

The generic boundaries of Acanthophyllum with its five small allied genera have been doubtful. Although inclusion of Allochrusa, Ochotonophila, and Scleranthopsis in Acanthophyllum was confirmed by previous molecular studies (Pirani \& al., 2014; Madhani \& al., 2018), the phylogenetic placement of the genera Diaphanoptera and Kuhitangia remained uncertain. The present study discusses the phylogenetic status of Diaphanoptera and Kuhitangia and further surveys the monophyly of traditional Allochrusa and its infrageneric taxa. Moreover, monophyly of the two heterogenic sections Macrostegia and Oligosperma is reassessed using additional Central Asiatic species. The sampled taxa were grouped within two well-supported clades in both the ITS and the rps16 tree (Fig. 2). These clades firmly correspond to the clades I and II in Pirani \& al. (2014). The obtained results are classified and interpreted below.

Phylogenetic position of Kuhitangia. - All three sampled specimens representing both recognized species of Kuhitangia nested within Acanthophyllum in both the ITS and the rps16 tree (Fig. 2), which confirms the inclusion of Kuhitangia within Acanthophyllum. These taxa reside within a monophyletic clade in the ITS tree (PP 0.97), but their relationship is not resolved in the rps16 tree (Fig. 2). Apart from the molecular data that confirm the inclusion of Kuhitangia within Acanthophyllum, morphological characters used by Ovczinnikov (1967) for describing Kuhitangia (long peduncles, petals lacking a claw, many-seeded capsules) are also found in Acanthophyllum. For example, long peduncles much exceeding the cushion are also seen in Acanthophyllum sect. Scapiflora Schiman-Czeika; non-clawed petals are seen in A. sordidum Bunge ex Boiss. and A. aphananthum; A. glandulosum Bunge ex Boiss. may contain many-seeded capsules (see Schiman-Czeika, 1988). Moreover, Acanthophyllum and Kuhitangia have also been separated based on their mode of capsule dehiscence, i.e., transverse rupture of capsule in Acanthophyllum, and capsule opening by four teeth in Kuhitangia (Bondarenko, 1971). However, capsule dehiscence into four valves has also been reported in Acanthophyllum (e.g., A. adenophorum Freyn, A. longicalyx Hedge \& Wendelbo, and A. laxiflorum Boiss.) (Schiman-Czeika, 1987). Therefore, we suggest treating Kuhitangia as a section of Acanthophyllum (see below).

Phylogenetic status of Diaphanoptera. - The type of the genus, Diaphanoptera khorasanica, is included in a strongly supported monophyletic clade together with $D$. lindbergii, $D$. stenocalycina, and $D$. transhyrcana within Acanthophyllum in both the ITS and the rps16 tree (Fig. 2). The generic positioning of $D$. transhyrcana, by traditional taxonomy, has been doubtful. It was first described as a species of Acanthophyllum (Preobraschensky, 1920). Schischkin (1936) also considered this taxon as a member of Acanthophyllum and placed it under subg. Allochrusa (Bunge) Schischk. Czerepanov (1981) transferred it to the genus Allochrusa, which he considered as distinct from Acanthophyllum. Ultimately this taxon was transferred to the genus Diaphanoptera by Rechinger \& Schiman-Czeika (1988).

Diaphanoptera ekbergii and D. afghanica fall outside of the core clade of Diaphanoptera. The ITS sequences of the latter 
reside outside of Acanthophyllum (see below under Non-functional paralogous sequence of Diaphanoptera afghanica and Saponaria kermanensis). Diaphanoptera ekbergii is the only member of this group with a prostrate habit and simple non-branched stems, while the other members of the genus are characterized by ascendant habit and branched stems.

We suggest reducing Diaphanoptera to a section of Acanthophyllum containing D. khorasanica, D. lindbergii, $D$. stenocalycina, and $D$. transhyrcana. The sectional position of $D$. ekbergii and $D$. afghanica cannot be resolved based on the available data and awaits more comprehensive studies.

Non-monophyly of Allochrusa. - After description of Allochrusa by Bunge (1867), the genus was included in Acanthophyllum by Golenkin (1893) and Schischkin (1936). Golenkin recognized Allochrusa at section rank, whereas Schischkin treated Allochrusa as a subgenus of Acanthophyllum and recognized two sections. One of these sections, i.e., sect. "Versicoloria Schischk." (this section’s name was later validated as sect. Allochrusa; Pirani \& Rabeler, 2017) occurs in the western part of the Caspian Sea, while the second group (sect. Paniculata Golenk.) occurs east of the Caspian Sea. Pirani \& al. (2014) showed that the investigated members of sect. Allochrusa (Al. bungei, Al. versicolor) and sect. Paniculata (Al. paniculata) resolve into two separate groups. Here, we have sampled two additional species assigned to sect. Allochrusa (Al. lutea, Al. persica), and two additional members of sect. Paniculata (Al. gypsophiloides, Al. tadshikistanica) to reassess the phylogenetic relationships among the elements of traditional Allochrusa. The present results firmly confirm the remote phylogenetic relationship between sect. Allochrusa and sect. Paniculata. Besides, both the ITS and the rps16 tree (Fig. 2) show that Al. tadshikistanica is not closely related to members of sect. Paniculata, rather it is allied to three members of sect. Macrostegia (e.g., A. coloratum, A. korolkowii, and A. sarawschanicum). Allochrusa tadshikistanica was first described as a species of Allochrusa (Schischkin, 1932). It was later transferred to Acanthophyllum subg. Allochrusa and classified within sect. Paniculata together with A. paniculatum Regel \& Herder and A. gypsophiloides Regel (Schischkin, 1936). It differs from the latter two taxa in having shorter petals (ca. equal to sepals) and bracts with membranous margins (versus exserted petals and scarious bracts in sect. Paniculata). Membranous bracts and bracteoles are among the distinctive features of sect. Macrostegia. We suggest that Al. tadshikistanica should be placed into a new section under Acanthophyllum (see below).

Inclusion of annual Saponaria results in a new concept of Acanthophyllum s.l. - The molecular survey of the tribe Caryophylleae by Madhani \& al. (2018) showed that the annual Saponaria viscosa had an odd phylogenetic position and resides as sister to Cyathophylla chlorifolia. As a result, they transferred S. viscosa to the genus Cyathophylla. This Cyathophylla clade (containing C. chlorifolia and C. viscosa (C.A.Mey.) Madhani \& Rabeler) can be considered as an appropriate outgroup for Acanthophyllum. We here tested the phylogenetic position of two more Irano-Turanian annual Saponaria species, i.e., S. kermanensis, and S. makranica. Surprisingly, both taxa resolved within Acanthophyllum (Fig. 2). This also contradicts the alternative treatment of S. kermanensis in Psammophiliella Ikonn. by Ikonnikov (1976) and S. makranica in Gypsophila by Ghazanafar (1986). Our results necessitate a revision of the concept of habit in Acanthophyllum s.l. Subshrubby to somewhat woody habit was used as key character to distinguish Acanthophyllum in the tribe Caryophylleae (Pirani \& al., 2014). The present results indicate that Acanthophyllum in a broad sense also contains annual non-woody elements. Furthermore, polyphyly of Saponaria is suggested as all of the examined annual species of the genus show a remote relationship with the biennial and perennial ones.

Monophyly of sect. Macrostegia and sect. Oligosperma. - Acanthophyllum sect. Macrostegia comprises 10 species in the Flora Iranica and the Flora of the U.S.S.R. areas (Schiman-Czeika, 1988; Schischkin, 1936). Almost half of the species of this section (A. coloratum, A. elongatum Preobr. ex Schischk., A. korolkowii, A. sarawschanicum) are endemic to Central Asia. Section Macrostegia appeared as monophyletic in the previous molecular study of the group, which mainly sampled SW Asiatic members of the section (Pirani \& al., 2014). In the present study, three of the four Central Asiatic species of this section were sampled as well. Analyzing data of both the nuclear and plastid markers showed that $A$. coloratum, A. korolkowii, and A. sarawschanicum, three non-spiny taxa assigned to sect. Macrostegia, do not group with the spiny members of the section. These three species resolved into a strongly supported clade (PP 1.0) together with Al. tadshikistanica on the ITS tree (Fig. 2). However, A. korolkowii does not group with A. coloratum, A. sarawschanicum, and Al. 
tadshikistanica in the rps16 tree (Fig. 2). The common feature between the latter and the three Central Asiatic species of sect. Macrostegia is non-spiny leaves. Here we suggest that taxa with non-spiny leaves should be excluded from sect. Macrostegia and transferred to a new section (sect. Pseudomacrostegia sect. nov., see below).

As the largest and taxonomically the most complicated group within Acanthophyllum, sect. Oligosperma contains about 30 species according to Schischkin (1936), Schiman-Czeika (1988), and Pirani \& al. (2013). Schischkin (1936) made a further division of this section and proposed five series (not validly published according to Art. 39.1 of the Shenzhen Code; Turland \& al., 2018), whereas Schiman-Czeika (1988) did not recognize these series. Eighteen species assigned to this section have already been investigated in the previous study by Pirani \& al. (2014) that showed the section is monophyletic, and that A. caespitosum should be excluded from the section. However, the relationships between species of the section remained largely unresolved. In the present study, five specimens representing four additional species of this section were studied. On the ITS tree, all sampled species of the section reside on a fully supported (PP 1.0) monophyletic group (Fig. 2). Except for A. andarabicum Podlech ex Schiman-Czeika and A. pulchrum, which fall out of the core clade of the section, the rest of the sampled species comprise a weakly supported (PP 0.87) monophyletic clade on the rps16 tree (Fig. 2). This difference between the ITS tree and the rps16 tree can be explained by different numbers of informative characters in nuclear and plastid datasets. Increased sampling in the present study was not of much help in resolving the relationships within the section. Furthermore, Schischkin's “series" did not resolve on the ITS and rps16 trees.

According to the results obtained, although two main clades are recognized within Acanthophyllum, these clades do not match the two subgenera (Acanthophyllum [= "Euacanthophyllum (Boiss.) Schischk.”], Allochrusa (Bunge) Schischk.) introduced by Schischkin (1936). As a consequence, the subgeneric classification of Acanthophyllum as suggested by Schischkin (1936) is not here confirmed. Moreover, based on our results, the number of sections within Acanthophyllum increases to at least 14. Since the ITS tree shows higher resolution, we have summarized the phylogenetic positions of these 14 sections on the ITS tree (Fig. 4). A list of species included in this study and their sectional placements based on the present results, as well as species with unresolved sectional positions, is presented in Table 1.

\section{Non-functional paralogous sequence of Diaphanoptera afghanica and Saponaria kermanensis. -}

Phylogeny relies on orthologous sequences, and using paralogous sequences and/or pseudogenes will result in an unreliable phylogenetic tree (Buckler \& al., 1997; Moazzeni \& al., 2014). Non-functional paralogues in ribosomal DNA (rDNA) or other genomes (e.g., mitochondrial genes) exist. Using the paralogues has already been reported for Caryophyllaceae (Popp \& Oxelman, 2004) and other angiosperms (Buckler \& al., 1997; Moazzeni \& al., 2014).

The secondary structure of ITS1 for Diaphanoptera afghanica obtained from type material (Podlech 21075 [MSB]) suggests that the divergent ITS allele is a non-functional paralogue. Thus, the placement of $D$. afghanica outside of the Acanthophyllum clade could possibly be explained by the inclusion of this paralogous copy in the phylogenetic analysis of Pirani \& al. (2014). In the present study, we re-sequenced ITS and rps16 markers from this specimen, but it failed for both markers. Regarding the morphological and geographical similarities of $D$. afghanica to the other species of the genus, it seems that a successful sequencing of orthologous alleles of this species would result in positioning of $D$. afghanica within the Acanthophyllum s.l. clade.

The highly conserved motif in ITS1 for KX184038 does not form a hairpin structure (data not shown), which means this divergent ITS allele is a non-functional paralogue. This might explain the remote positioning of the two Saponaria kermanensis samples both inside (KX184037) and outside (KX184038) of Acanthophyllum. Since the orthologue sequence (KX184037) resides within Acanthophyllum, it seems that S. kermanensis should be considered as a member of this clade.

Conclusions. - Recent molecular studies have notably improved our knowledge about generic delimitation and infrageneric classification of Acanthophyllum. However, sectional position of several species is still unclear. Moreover, species relationships within sect. Acanthophyllum and sect. Oligosperma have largely remained unresolved. Using additional molecular markers in future research on the genus would help to address these issues. A comprehensive molecular study on Saponaria, including all annual species, would also be another direction for future studies and help clarify generic boundaries 
among Saponaria and allied genera, e.g., Acanthophyllum and Gypsophila.

New names and combinations. - In addition to the three new sections and combinations necessary for treating Diaphanoptera and Kuhitanigia species as members of Acanthophyllum, combinations are made for two species of Saponaria, and one species each of Ochotonophila and Allochrusa that were described close to, or after, Pirani \& al. (2014) was published.

Acanthophyllum sect. Diaphanoptera (Rech.f.) A.Pirani \& Moazzeni, comb. \& stat. nov. $\equiv$ Diaphanoptera Rech.f. in Repert. Spec. Nov. Regni Veg. 48: 41. 1940 - Type: Diaphanoptera khorasanica Rech.f.

Diagnosis. - Perennial, low-growing plants, woody at base, multi-stemmed. Leaves non-spiny. Inflorescences with short peduncles, partial inflorescences lax dichasia, cymes or thyrses. Bracts and bracteoles leafy. Calyx with $5 \pm$ prominent wings or nerves. Petals clawed. Ovary stipitate, ovules 6-19; capsules many-seeded, opening through four valves.

Acanthophyllum sect. Kuhitangia (Ovcz.) A.Pirani \& Kovalchuk, comb. \& stat. nov. $\equiv$ Kuhitangia Ovcz. in Dokl. Akad. Nauk Tadzhiksk. S.S.R. 10: 50. 1967 - Type: Acanthophyllum popovii (Preobr.) Barkoudah.

Diagnosis. - Perennial subshrubs, woody at base, cushion-forming. Leaves spiny. Inflorescences with long leafless peduncles prominently exceeding the cushion, partial inflorescences \pm dense cymes. Bracts and bracteoles acicular. Calyx lacks wings or prominent nerves. Petals lack a claw. Ovary with short stipe, many-ovuled; capsules many-seeded, opening through four valves.

Acanthophyllum sect. Pseudomacrostegia A.Pirani, Kovalchuk \& A.Pavlenko, sect. nov. - Type: Acanthophyllum sarawschanicum Golenk.

Diagnosis. - Perennial subshrubs, woody at base, non-cushion-forming. Leaves non-spiny. Inflorescences with \pm long peduncles, partial inflorescences \pm dense globose cymes or 3-flowered dichasia (in A. tadshikistanica). Bracts and bracteoles membranous or broadly hyaline margined, non-acicular. Calyx lacks wings or prominent nerves. Petals clawed. Ovary with short stipe, 4-ovuled; capsules one-seeded.

Acanthophyllum afghanicum (Podlech) A.Pirani \& Zarre, comb. nov. ミDiaphanoptera afghanica Podlech in Mitt. Bot. Staatssamml. München 16: 542. 1980 - Holotype: Afghanistan. Prov. Baghlan: Andarab Tal, 5 km E Doshi, 920 m, 6 May 1971, Podlech 21075 (M n.v. [per Podlech, 1980]; isotypes: G barcode G00226761 [image online!], W No. 0048191 [isotype fragments, image online!]).

Acanthophyllum diaphanopterum A.Pirani \& Moazzeni, nom. nov. $\equiv$ Diaphanoptera khorasanica Rech.f. in Repert. Spec. Nov. Regni Veg. 48: 42. 1940, non Acanthophyllum khorasanicum Rech.f. in Repert. Spec. Nov. Regni Veg. 48: 43.1940 - Holotype: Iran. Robat Safid inter Mashhad et Torbat-e Heydariyeh, 1700 m, 10 Jul 1937, Rechinger 1515 (W No. 1963-0003850 [image online!]; isotypes: BM barcode BM000522099 [image online!], K barcode K000742100 [image online!], NY barcode 00342485 [image online!], S No. S-G-8646 [image online!].

Acanthophyllum ekbergii (Hedge \& Wendelbo) A.Pirani \& Rabeler, comb. nov. 三 Diaphanoptera ekbergii Hedge \& Wendelbo in Notes Roy. Bot. Gard. Edinburgh 31(2): 333. 1972 - Holotype: Afghanistan. Prov. Baghlan, N side of Salang Pass, 3200 m, 22 Jul 1969, Wendelbo \& Ekberg W-9844 (E barcode E00301816 [image online!]; isotypes: G barcode G00226756 [image online!], GB barcode GB-0047146! [image online!], W No. 1972-0007315 [image online!]).

Acanthophyllum flavum (Dickoré \& Freitag) A.Pirani \& Rabeler, comb. nov. $\equiv$ Ochotonophila flava Dickoré \& Freitag in Edinburgh J. Bot. 70(3): 406. 2013 - Holotype: Afghanistan, Bamiyan Prov., 6.4 km SSE of Bamiyan [city], 2729 m, 
34.7697 N, 67.8505², 03 Jun 2008, Jacobs \& Schloeder 1664 (M barcode M-0164353 [image online!]; isotype: E n.v. [fide Dickoré \& Freitag, 2013]).

Acanthophyllum kermanense (Bornm.) A.Pirani \& Rabeler, comb. nov. $\equiv$ Saponaria kermanensis Bornm. in Repert. Spec. Nov. Regni Veg. 6: 302. 1909 E Psammophila kermanensis (Bornm.) Ikonn. in Novosti Sist. Vyssh. Rast. 8: 273. $1971 \equiv$ Psammophiliella kermanensis (Bornm.) Ikonn. in Novosti Sist. Vyssh. Rast. 13: 117. 1976 - Lectotype (designated here): Iran. Kuh i-Jupar, 2900-3800 m, 4 Jun 1892, Bornmüller 2265, Iter Persico-Turcicum 1892-93 (JE barcode JE00016782 [image online!]; isotypes: K barcode K000725823 [image online!], P barcode P05017980 [image online!], WU No. 0107077 [image online!]).

Bornmüller did not indicate the location of the specimen cited in the protologue (Bornmüller, 1909). Bornmüller’s original herbarium, including "zahlreichen darin enthaltenen Typen neuer Taxa" (numerous types of new taxa contained therein), was presented to B in 1938 (Wagenitz, 1960: 358). This suggests that it was his intent to have the type specimen of S. kermanensis at B. We are designating a lectotype for Saponaria kermanensis since the Caryophyllaceae (except for some Paronychioideae) was included in the list of 32 families that Wagenitz (1960) noted as "destroyed" during World War II. Of the four specimens of Bornmüller 2265 that we located, the specimen at JE is chosen as the lectotype. Bornmüller was curator at JE (Herbarium Haussknecht) from 1904 to 1938 (Stafleu \& Mennega, 1993) and, since some of the specimens of this collection may have been distributed in 1896 (see "Recd" on the K specimen and "Recu" on the P specimen), it seems likely that he would have had access to this specimen as well as that in his personal herbarium at the time of the publication of the protologue.

Acanthophyllum lindbergii (Hedge \& Wendelbo) A.Pirani \& Oxelman, comb. nov. $\equiv$ Diaphanoptera lindbergii Hedge \& Wendelbo in Arbok Univ. Bergen, Mat.-Naturvitensk. Ser., 18: 18. 1964 (“1963”)- Holotype: Afghanistan. Inter Belchiragh et Darrah Abdullah, 1100 m, 28 May 1962, Hedge \& Wendelbo W-3692 (E barcode E00301815 [image online!]; isotypes: BG n.v., W No. 1972-0007395 [image online!]).

Acanthophyllum luteum (Falat. \& Mahmoodi) A.Pirani \& Kovalchuk, comb. nov. $\equiv$ Allochrusa lutea Falat. \& Mahmoodi in Phytotaxa 277(2): 193. 2016 - Holotype: Iran. Zanjan province, $20 \mathrm{~km}$ on the Zanjan-Tabriz road, beginning of EsfejinMirjan road, 1570 m, 36 44'22.38"N, 48¹4'35.88"E, 5 Jun 2016, Mahmoodi \& Ashrafi 100472 (TARI!).

Acanthophyllum makranicum (Rech.f.) A.Pirani \& Rabeler, comb. nov. 三 Saponaria makranica Rech.f. in Pl. Syst. Evol. 141: 83. $1982 \equiv$ Gypsophila makranica (Rech.f.) Ghaz. in Nasir \& Ali, Fl. Pakistan 175: 94.1986 - Holotype: Pakistan. Makran: Nag inter Panjgur et Surab, Substr. Tonschiefer, 1300 m, 26 $6^{\circ} 58^{\prime} \mathrm{N}, 64^{\circ} 06^{\prime} \mathrm{E}, 21$ Apr 1965, Rechinger28265 (W No. 1994-0007441 [image online!]; isotypes: B barcode B 100366295 [image online!], G, barcode G00226955 [image online!], GZU [herb. Rechinger] barcode GZU000273158 [image online!], K, barcode K000725827 [image online!]).

Acanthophyllum stenocalycinum (Rech.f. \& Schiman-Czeika) A.Pirani \& Moazzeni, comb. nov. $\equiv$ Diaphanoptera stenocalycina Rech.f. \& Schiman-Czeika in Rechinger, Fl. Iranica 163: 334. 1988 - Holotype: Iran. [Golestan National Park] planitie "dasht” ad viam versus Almeh ducentem N Rebat-e Qareh Bil, 1200 m, 37 $19^{\prime} \mathrm{N}, 56^{\circ} 26^{\prime} \mathrm{E}, 5 \mathrm{Jun} 1975$, Rechinger 52881 (W No. 1988-0009800 [image online!]; isotypes: B barcode B 10 0365634! [image online!]; E barcode E00301814 [image online!], G barcode G00226755 [image online!], GZU barcode GZU000273151 [image online!], MA barcode MA 496942 [image online!], S No. S-G-8645 [image online!], WU No. 0035437! [image online!]. 


\section{AUTHOR CONTRIBUTIONS}

AP: Supervising the study, specimen study, plant collection, laboratory procedures, molecular analyses, manuscript preparation. HM: Plant collection, laboratory procedures, molecular analyses, manuscript revision. SZ: Providing some sequences, manuscript revision. RKR: Nomenclatural editing, manuscript revision, providing some references, some taxonomic novelties in the study group. BO: Providing some sequences, manuscript revision. AVP: Specimen study, plant collection. AK: Specimen study, plant collection, laboratory procedures, manuscript revision. — AP, https://orcid.org/0000-0003-4937-5711, apirani@um.ac.ir; HM, http://orcid.org/0000-0002-2406-2666, hmoazzeni@um.ac.ir; SZ, https://orcid.org/0000-0001-9159-1800, zarre@khayam.ut.ac.ir; RKR, https://orcid.org/0000-0002-6765-0353, rabeler@umich.edu; BO, https://orcid.org/0000-0002-6104-4264, bengt.oxelman@bioenv.gu.se; AVP, https://orcid.org/0000-0003-2494-02, alexpavlenko1974@gmail.com; AK, https://orcid.org/0000-0001-8704-4644, andriy.kovalchuk@helsinki.fi.

\section{ACKNOWLEDGMENTS}

We are grateful to Mohammad Mahmoodi (Research Institute of Forests and Rangelands, Tehran), Jalil Noroozi (University of Vienna, Vienna), Saeide Hoseini (Ferdowsi University of Mashhad, Mashhad), Farshid Memariani (Ferdowsi University of Mashhad, Mashhad), Alexey Grebenjuk (Komarov Botanical Institute of the Russian Academy of Sciences, St. Petersburg), Aleksandr Ebel (Tomsk State University, Tomsk), Alim Gaziev (Tashkent), and Georgy Lazkov (Institute for Biology, National Academy of Sciences, Bishkek), for their kind help during different steps of this work. We also wish to thank curators at B, BM, FUMH, G, GB, H, JE, K, LD, LE, M, MSB, TARI, TASH, TK, TMRC, TUH and WU for the loan and permission to study plant material used in this study. The herbarium of RBG Edinburgh (E) is thanked for providing photos of their Acanthophyllum s.l. specimens. James Solomon (MO) kindly provided a copy of Preobraschensky (1920). Financial support provided by the Ferdowsi University of Mashhad (Grant No. 41705-2) is appreciated.

\section{LITERATURE CITED}

Barkoudah, Y.I. 1962. A revision of Gypsophila, Bolanthus, Ankyropetalum and Phryna. Wentia 9: 1-203.

Bittrich, V. 1993. Caryophyllaceae. Pp. 206-236 in: Kubitzki, J., Rohwer, J.G. \& Bittrich, V. (eds.), The families and genera of vascular plants, vol. 2. Berlin: Springer. https://doi.org/10.1007/978-3-662-02899-5_21

Bondarenko, O.N. 1971. Sem, Caryophyllaceae - Gvozdichnye [Family Caryophyllaceae] (pro parte). Pp. 225-310 in: Vvedensky, A.I. \& Kovalevskaja, S.S. (eds.), Conspectus florae Asiae Mediae, vol. 2. Tashkent: Editio Academiae Scientarum UzSSR. [in Russian].

Bornmüller, J. 1909. Saponaria Kermanensis Bornm. Nov. spec. sectionis Proteiniae e flora Persiae austro-orientalis. Repert. Spec. Nov. Regni Veg. 6: 302-303.

Buckler, E.S., Ippolito, A. \& Holtsford, T.P. 1997. The evolution of ribosomal DNA divergent paralogues and phylogenetic implications. Genetics 145: 821-832.

Bunge, A. von 1867. Allochrusa. Pp. 559-560 in: Boissier, E. (ed.), Flora Orientalis, vol. 1. Basileae [Basel]: apud H. Georg. Genevae [Geneva]: apud Eumden. https://doi.org/10.5962/bhl.title.20323

Czerepanov, S.K. 1981. Sosudistye Rasteniia SSSR. Leningrad: Nauka, Leningradskoe Otd-nie. [in Russian]

Darriba, D., Taboada, G.L., Doallo, R. \& Posada, D. 2012. jModelTest 2: More models, new heuristics and parallel computing. Nature, Meth. 9: 772. 
Dickoré, W.B., Schloeder, C., Jacobs, M., Spribille, T. \& Freitag, H. 2013. Ochotonophila flava (Caryophyllaceae), a new species from central Afghanistan. Edinburgh J. Bot. 70(3): 405-412.

Doyle, J.J. \& Doyle, J.L. 1987. A rapid DNA isolation procedure for small quantities of fresh leaf tissue. Phytochem Bull. Bot. Soc. Amer. 19: 11-15.

Eggens, F., Popp, M., Nepokroeff, M., Wagner, W.L. \& Oxelman, B. 2007. The origin and number of introductions of the Hawaiian endemic Silene species (Caryophyllaceae). Amer. J. Bot. 94: 210-218.

Ghazanafar, S.A. 1986. Caryophyllaceae. Pp. 1-125 in: Nasir, E. \& Ali, S.I. (eds.), Flora of Pakistan, vol. 175. Islamabad: Pakistan Agricultural Research Council.

Golenkin, M. 1893. Verzeichniss der Arten der Gattung Acanthophyllum C.A. Meyer. Trudy Imp. S.-Peterburgsk. Bot. Sada 13: 77-87.

Hernández-Ledesma, P., Walter, G., Berendsohn, W.G., Borsch, T., Mering, S. von, Akhani, H., Arias, S., Castañeda-Noa, I., Eggli, U., Eriksson, R., Flores-Olvera, H., Fuentes-Bazán, S., Kadereit, G., Klak, C., Korotkova, N., Nyffeler, R., Ocampo, G., Ochoterena, H., Oxelman, B., Rabeler, R.K., Sanchez, A., Schlumpberger, B.O. \& Uotila, P. 2015. A taxonomic backbone for the global synthesis of species diversity in the angiosperm order Caryophyllales. Willdenowia 45: 281-383. https://doi.org/10.3372/wi.45.45301

Huelsenbeck, J.P. \& Ronquist, F. 2001. MrBayes: Bayesian inference of phylogenetic trees. Bioinformatics 17: 754-755.

Ikonnikov, S.S. 1976. Notes on Caryophyllaceae, 3. On the genus Psammophiliella Ikonn. Novosti Sist. Vyssh. Rast. 13: 116117. [in Russian]

Joly, S., Starr, J.R., Lewis, W.H. \& Bruneau, A. 2006. Polyploid and hybrid evolution in roses east of the Rocky Mountains. Amer. J. Bot. 93: 412-425.

Kiani, M., Zarghami, H., Memariani, F. \& Tehranifar, A. 2013. In vitro propagation and conservation of Diaphanoptera khorasanica (Caryophyllaceae), a threatened endemic and potential ornamental species in northeast of Iran. J. Cell Molec. Res. 4: 89-96.

Liu, J. \& Schardl, C.L. 1994. A conserved sequence in internal transcribed spacer 1 of plant nuclear rRNA genes. Pl. Molec. Biol. 26: 775-778.

Madhani, H., Rabeler, R., Pirani, A., Oxelman, B., Heubl, G. \& Zarre, S. 2018. Untangling phylogenetic patterns and taxonomic confusion in tribe Caryophylleae (Caryophyllaceae) with special focus on generic boundaries. Taxon 67: 83112.

Mahmoodi, M. \& Nejad Falatoury, A. 2016. Allochrusa lutea (Caryophylloideae, Caryophyllaceae) a new species from Iran. Phytotaxa 277: 191-198.

Minh, B.Q., Nguyen, M.A.T. \& Haeseler, A. von 2013. Ultrafast approximation for phylogenetic bootstrap. Molec. Biol. Evol. 30: 1188-1195.

Moazzeni, H., Zarre, S., Pfeil, B.E., Bertrand, Y.J.K., German, D.A., Al-Shehbaz, I.A., Mummenhoff, K. \& Oxelman, B. 2014. Phylogenetic perspectives on diversification and character evolution in the species-rich genus Erysimum (Erysimeae; Brassicaceae) based on a densely sampled ITS approach. Bot. J. Linn. Soc. 175: 497-522.

Noroozi, J., Pirani, A., Moazzeni, H., Mahmoodi, M., Zare, G., Norrmohammadi, A., Barfuss, M.H.J., Suen, M. \& Schneeweiss, G.M. 2020. The new locally endemic genus Yazdana (Caryophyllaceae) and patterns of endemism highlight the high conservation priority of the poorly studied Shirkuh Mountains (central Iran). J. Syst. Evol. 58(3): 339353. https://doi.org/10.1111/jse.12575

Ovczinnikov, P.N. 1967. Novyj rod iz semejstva Gvozdichnyh Pamiro-Alaya - Kuhitangia (Kuhitangia Ovcz., gen. nov.) [A new genus of family Caryophyllaceae from Pamiro-Alay - Kuhitangia (Kuhitangia Ovcz., gen. nov.)]. Dokl. Akad. Nauk Tadzhiksk. S.S.R. 10(7): 50-52. [in Russian]

Ovczinnikov, P.N. 1968. Flora Tadzhikskoi SSR, vol. 3, Orekhovye-Gvozdichnye. Leningrad: Izdatelstvo Nauka. [in Russian] 
Oxelman, B., Lidén, M. \& Berglund, D. 1997. Chloroplast rps16 intron phylogeny of the tribe Sileneae (Caryophyllaceae). Pl. Syst. Evol. 206: 393-410.

Pirani, A., Joharchi, M.R. \& Memariani, F. 2013. A new species of Acanthophyllum (Caryophyllaceae) from Iran. Phytotaxa 92: 20-24. https://doi.org/10.11646/phytotaxa.92.1.3

Pirani, A. \& Rabeler, R.K. 2017. Nomenclatural notes on Acanthophyllum (Caryophylleae, Caryophyllaceae). Phytotaxa 303: 197-198.

Pirani, A., Zarre, S., Pfeil, B.E., Bertrand, Y.J.K., Assadi, M. \& Oxelman, B. 2014. Molecular phylogeny of Acanthophyllum (Caryophyllaceae: Caryophylleae), with emphasis on infrageneric classification. Taxon 63: 592-607. https://doi.org/10.12705/633.39

Podlech, D. 1980. Neue und bemerkenswerte Caryophyllaceen aus Afghanistan (Beiträge zur Flora von Afghanistan XI). Mitt. Bot. Staatssamml. München 16: 529-546.

Popp, M. \& Oxelman, B. 2001. Inferring the history of the polyploid Silene aegaea (Caryophyllaceae) using plastid and homoeologous nuclear DNA sequences. Molec. Phylogen. Evol. 20: 474-481.

Popp, M. \& Oxelman, B. 2004. Evolution of a RNA polymerase gene family in Silene (Caryophyllaceae) — Incomplete concerted evolution and topological congruence among paralogues. Syst. Biol. 53: 914-932. https://doi.org/10.1080/10635150490888840

Popp, M. \& Oxelman, B. 2007. Origin and evolution of North American polyploid Silene (Caryophyllaceae). Amer. J. Bot. 94: 330-349.

Popp, M., Erixon, P., Eggens, F. \& Oxelman, B. 2005. Origin and evolution of a circumpolar polyploid species complex in Silene (Caryophyllaceae) inferred from low copy nuclear RNA polymerase introns, rDNA, and chloroplast DNA. Syst. Bot. 30: 302-313.

Preobraschensky, G.A. 1920. Acanthophyllum transhyrcanum G. Preobr. Bot. Mater. Gerb. Glavn. Bot. Sada R.S.F.S.R. 1(3): 1-3. [in Russian]

Rechinger, K.H. 1940. Plantae novae iranicae I. Repert. Spec. Nov. Regni Veg. 48: 33-48.

Rechinger, K.H. \& Schiman-Czeika, H. 1988. Diaphanoptera. Pp. 332-337 in: Rechinger, K.H. (ed.), Flora Iranica, vol. 163. Graz: Akademische Druck- u. Verlagsanstalt.

Schiman-Czeika, H. 1987. Notes on the capsule dehiscence in Acanthophyllum (Caryophyllaceae) and allied genera. Pl. Syst. Evol. 155: 67-69. https://doi.org/10.1007/BF00936289

Schiman-Czeika, H. 1988. Acanthophyllum. Pp. 253-329 in: Rechinger, K.H. (ed.), Flora Iranica, vol. 163. Graz: Akademische Druck- u. Verlagsanstalt.

Schischkin, B.K. 1932. De quibusdam plantis novis Asiae mediae e familia Caryophyllacearum. Trudy Bot. Muz. 24: 38-41.

Schischkin, B.K. 1936. Acanthophyllum. Pp. 781-802, 892-896 in: Komarov, V.L. \& Shishkin., B.K. (eds.), Flora of the U.S.S.R., vol. 6. Moscow \& Leningrad: Izdatel'stvo Akademii Nauk SSSR. [in Russian]

Stafleu, F. \& Mennega, E.A. 1993. Taxonomic literature: A selective guide to botanical publications and collections with dates, commentaries and types, suppl. 2, Be-Bo. Regnum Vegetabile 130. Königstein: Koeltz Scientific Books.

Takhtajan, A. 2009. Flowering plants, 2nd ed. Dordrecht: Springer. https://doi.org/10.1007/978-1-4020-9609-9

Turland, N.J., Wiersema, J.H., Barrie, F.R., Greuter, W., Hawksworth, D.L., Herendeen, P.S., Knapp, S., Kusber, W.-H., Li, D.-Z., Marhold, K., May, T.W., McNeill, J., Monro, A.M., Prado, J., Price, M.J. \& Smith, G.F. (eds.) 2018. International Code of Nomenclature for algae, fungi, and plants (Shenzhen Code), adopted by the Nineteenth International Botanical Congress, Shenzhen, China, July 2017. Regnum Vegetabile 159. Glashütten: Koeltz Botanical Books. https://doi.org/10.12705/Code.2018

Valente, L.M., Savolainen, V. \& Vargas, P. 2010. Unparalleled rates of species diversification in Europe. Proc. Roy. Soc. London, Ser. B, Biol. Sci. 277: 1489-1496. https:// doi.org/10.1098/rspb.2009.2163

Wagenitz, G. 1960. Joseph Bornmüller. Willdenowia 2(3): 343-360. 
Appendix 1. Voucher information.

Species name, geographic origin, collector(s), voucher, (herbarium), GenBank accession numbers for ITS and rps16, respectively (* indicates sequences generated in this study; - indicates missing data).

Acanthophyllum acerosum Sosn., Iran, W Azarbaijan, Zarre \& al. 41900 (TUH), KF924680, KF924732; Acanthophyllum aculeatum Schischk., Uzbekistan, Nuratau mountains, Qo’ytosh range, Botschantzev \& Kamelin 01042334 (LE), *MN310905, *MN310752; Acanthophyllum adenophorum Freyn, Iran, Khorassan, Pirani \& Moazzeni 1947 (TMRC), KF924679, KF924731; Acanthophyllum allochrusoides (Gilli) A.Pirani, Afghanistan, Bamian, Wendelbo \& Ekberg W9801 (GB), KF924627, KF924682; Acanthophyllum andarabicum Podlech ex Schiman-Czeika, Afghanistan, Baghlan, Podlech 10985 (MSB), KF924678, KF924730; Acanthophyllum andersenii Rech.f. \& Schiman-Czeika, Iran, Khorassan, Anders \& Peterson 320 (GB), KF924677, KF924729; Acanthophyllum anisocladum Schiman-Czeika, Afghanistan, Lugar, Ekberg W9180 (GB), KF924676, KF924728; Acanthophyllum aphananthum Rech.f., Afghanistan, Kabul, Rechinger 31265 (M), KF924626, KF924681; Acanthophyllum borsczowii Litv., Iran, Khorassan, Zarre \& al. 41034 (TUH), KF924675, KF924727; Acanthophyllum bracteatum Boiss., Iran, Kohghiluyeh \& Boyerahmad, Pirani \& Moazzeni 2104 (TMRC), KF924674, KF924726; Acanthophyllum caespitosum Boiss., Iran, Hamadan, Zarre \& al. 41903 (TUH), KF924673, KF924725; Acanthophyllum cerastioides (D.Don) Madhani \& Zarre, NW Pakistan, Swat, in valle Jabba E Kolalai, substr. Granit, 1600-2200 m, 4 Jun 1965, Rechinger 30724 (M), MF401122, MF401168; Acanthophyllum coloratum Schischk., Kyrgyzstan, jugum Ferganense, declive generale boreali-orientale, systema fl. Alabuga, 2400 m, 6 Aug1995, Lazkov \& Milko 01042337 (LE), *MN310906, *MN310753; Acanthophyllum crassifolium Boiss., Iran, Mazandaran, Pirani \& Moazzeni 41702 (TUH), KF924672, KF924724; Acanthophyllum crassinodum Yukhan. \& J.R.Edm., Iran, Kerman, Pirani \& Moazzeni 2923 (TMRC), KF924671, KF924723; Acanthophyllum diezianum Hand.-Mazz., Iran, Khorassan, Zarre \& al. 41040 (TUH), KF924670, KF924722; Acanthophyllum ejtehadii Mahmoudi \& Vaezi, Iran, Khorassan, Pirani \& Moazzeni 2181 (TMRC), KF924669, KF924721; Acanthophyllum elatius Bunge 1, Turkmenistan, Karakum desert, sands near lake Ýasga, Rodin \& al. 01042340 (LE), *MN310907, *MN310754; Acanthophyllum elatius 2, Tajikistan, Amu Darya basin, sand ripple on the second terrace, Nikitin 01042342 (LE), *MN310908, *MN310755; Acanthophyllum glandulosum Bunge ex Boiss., Iran, Khorassan, Zarre \& al. 41037 (TUH), KF924668, KF924720; Acanthophyllum gracile Bunge ex Boiss., Iran, Semnan, Pirani \& Moazzeni 2989 (TMRC), KF924667, KF924719; Acanthophyllum grandiflorum Stocks, Afghanistan, Bamian, Podlech 1340 (MSB), KF924666, KF924718; Acanthophyllum gypsophiloides Regel 1, Kazakhstan, Karatau mountains, Boralday range, Koshkarata river valley, Ebel 004118 (TK), *MN310913, *MN310760; Acanthophyllum gypsophiloides 2, Uzbekistan, Tashkent region, clayey-stony slope above Chatkal river, 9 Jun 2015, Gaziev iso- H 1773967 (TASH), *MN310914, *MN310761; Acanthophyllum heratense Schiman-Czeika, Iran, Isfahan, Pirani \& Moazzeni 2152 (TMRC), KF924665, KF924717; Acanthophyllum herniarioides (Boiss.) Madhani \& Zarre, Tajikistan, N von Dushanbe Anzob-Pass im Gissar-Massiv, ca. 3400 m, 14 Jul 1975, Mueller-Doblies 75083 (B), MF401123, -; Acanthophyllum heterophyllum Rech.f., Iran, Kerman, Pirani \& Moazzeni 2921 (TMRC), KF924664, KF924716; Acanthophyllum honigbergeri (Fenzl) Barkoudah, E Afghanistan, Gardes, in altoplanitie lapidosa vallis Logar $50 \mathrm{~km} \mathrm{~N}$ Gardez, 333’ $\mathrm{N}$ 6909'E, 2000 m, Rechinger 35371 (B), MF401125, MF401176; Acanthophyllum kabulicum Schiman-Czeika, Afghanistan, Ghazni, Frey s.n. (GB), KF924663, KF924715; Acanthophyllum kandaharicum Gilli, Iran, Khorassan, Joharchi \& Zangouei 36245 (FUMH), KF924662, KF924714; Acanthophyllum korolkowii Regel \& Schmalh., Turkmenistan, SW part of Uchtagan 
sands, semi-fixed sands, Pavlenko 1773968 (H), *MN310909, *MN310756; Acanthophyllum korshinskyi Schischk., Iran, Khorassan, Pirani \& Moazzeni 2123 (TMRC), KF924661, KF924713; Acanthophyllum kurdicum Boiss. \& Hausskn. ex Boiss., Iran, Ilam, Hamzehee \& Lashkarbolooki 1756 (TARI), KF924660, KF924712; Acanthophyllum laxiflorum Boiss., Afghanistan, Lugar, Ekberg W9184 (GB), KF924659, KF924711; Acanthophyllum laxiusculum Schiman-Czeika, Iran, Qom, Pirani \& Moazzeni 1941 (TMRC), KF924658, KF924710; Acanthophyllum leucostegium Schiman-Czeika, Iran, Bandar Abbas, Ghahreman \& Mozaffarian 5656 (TUH), KF924657, KF924709; Acanthophyllum lilacinum Schischk., Afghanistan, Badghis, Podlech \& Jarmal 29855 (MSB), KF924656, -; Acanthophyllum longicalyx Hedge \& Wendelbo, Afghanistan, Jawzjan, Freitag 6580 (MSB), KF924655, KF924708; Acanthophyllum macrodon Edgew., Afghanistan, Kandahar, Hedge \& al. W7641 (GB), KF924654, KF924707; Acanthophyllum microcephalum Boiss., Iran, Tehran, Rajamand \& Bazargan 32055 (TARI), KF924653, KF924706; Acanthophyllum mucronatum C.A.Mey., Iran, W Azarbaijan, Assadi \& Olfat 68668 (TARI), KF924652, KF924705; Acanthophyllum myrianthum (Rech.f.) Madhani \& A.Pirani, C Afghanistan, Deh Kundi: in saxosis $10 \mathrm{~km}$ w Shahrestan, $33^{\circ} 40^{\prime} \mathrm{N} 66^{\circ} 35^{\prime} \mathrm{E}$, versus Deh Kundi, $34^{\circ} 10^{\prime} \mathrm{N} 66^{\circ} 07^{\prime} \mathrm{E}$, 2200 m, 1967, Rechinger 36812 (B), MF401124, -; Acanthophyllum oppositiflorum Aytaç, Turkey, Sivas, Aytaç 7476 (GAZI), KF924651, KF924704; Acanthophyllum pachycephalum Schiman-Czeika, Iran, Tehran, Ganjalizadeh 6106 (TUH), KF924650, KF924703; Acanthophyllum pachystegium Rech.f., Afghanistan, Badakhshan, Hedge \& Wendelbo W9282 (GB), KF924649, KF924702; Acanthophyllum paniculatum Regel \& Herder, [no detailed data available], JN589016, -; Acanthophyllum pleiostegium Schiman-Czeika, Afghanistan, Kataghan, Grey-Wilson \& Hewer 1320 (GB), KF924648, KF924701; Acanthophyllum pulchrum Schischk., Tajikistan, stony slopes at Panj river, Botschantzev \& Egorova 01042349 (LE), *MN310910, *MN310757; Acanthophyllum pungens (Bunge) Boiss., Kazakhstan, NW ridges of Dzungarian Alatau, hamada, Goloskokov 01042352 (LE), *MN310911, *MN310758; Acanthophyllum raphiophyllum (Rech.f.) Barkoudah, Afghanistan, Kapisa, Podlech 12548 (MSB), KF924647, KF924700; Acanthophyllum sarawschanicum Golenkin, Uzbekistan, Kyr-Tau mountains, Kamelin \& al. 01042363 (LE), *MN310912, *MN310759; Acanthophyllum scapiflorum (Akhtar) Schiman-Czeika, Afghanistan, Kabul, Podlech 31232 (MSB), KF924646, KF924699; Acanthophyllum schugnanicum Schischk., Afghanistan, Bamian, Wendelbo \& Ekberg W9796 (GB), KF924645, KF924698; Acanthophyllum sordidum Bunge ex Boiss., Iran, Isfahan, Pirani \& Moazzeni 2147 (TMRC), KF924644, KF924697; Acanthophyllum speciosum Rech.f. \& Schiman-Czeika, Iran, Khorassan, Pirani \& Moazzeni 2186 (TMRC), KF924643, KF924733; Acanthophyllum spinosum C.A.Mey., Iran, Isfahan, Pirani \& Moazzeni 2150 (TMRC), KF924642, KF924696; Acanthophyllum squarrosum Boiss., Iran, Semnan, Pirani \& Moazzeni 2974 (TMRC), KF924641, KF924695; Acanthophyllum stewartii (Thoms. ex Edgew. \& Hook.f.) Barkoudah, Afghanistan, Khost, Anders 8994 (MSB), KF924640, KF924694; Acanthophyllum stocksianum Boiss., Afghanistan, Kandahar, Toncev s.n. (MSB), KF924639, KF924693; Acanthophyllum subglabrum Schischk., Afghanistan, Nangarhar, Hedge \& al. W7483 (GB), KF924638, KF924692; Acanthophyllum tadshikistanicum (Schischk.) Schischk., Tajikistan, Kara-Tau mountains, W of bridge over Kyzyl-Su river, crevices of limestone rocks, Botschantzev \& Egorova 01020716 (LE), *MN310917, *MN310764; Acanthophyllum verticillatum Hand.-Mazz., Iran, Markazi, Mozaffarian \& Sardabi 42175 (TARI), KF924637, KF924691; Acanthophyllum xanthoporphyranthum Hedge \& Wendelbo, Afghanistan, Herat, Hedge \& al. W8003 (GB), KF924636, KF924690; Acanthophyllum yasamin-nassehiae Joharchi \& Pirani, Iran, Khorassan, Memariani \& Zangouei 41448 (FUMH), KF924635, KF924689; Allochrusa bungei Boiss., Iran, E Azarbaijan, Rechinger 43834 (M), KF924634, KF924688; Allochrusa lutea Falat. \& Mahmoodi, Iran, Zanjan, Mahmoodi \& Ashrafi 100481 (TARI), *MN310915, *MN310762; Allochrusa persica Boiss., Iran, East Azarbayejan, Assadi \& Mozaffarian 30542 (TARI), *MN310916, *MN310763; Allochrusa versicolor (Fisch. \& C.A.Mey.) Boiss., Turkey, Kars, Nydegger 43597b (MSB), KF924633, KF924687; Cyathophylla viscosa (C.A.Mey.) Madhani \& Rabeler, Armenia, Vayotsdzor Prov., Vajk Distr, road Vajk-Kochbek, ca. 8 km ENE Vajk, gorge of Darab river, sandy area, 1380 m, 26 Jun 2002, Optima Iter XI/1846 (M), MF401117, MF401165; Diaphanoptera afghanica Podlech, Afghanistan, Baghlan, Podlech 21075 (MSB), KF924632, -; Diaphanoptera ekbergii Hedge \& Wendelbo, Afghanistan, Takhar, Podlech 11848 (MSB) \& 11760 (MSB), KF924631, KF924686; Diaphanoptera 
khorasanica Rech.f., Iran, Khorassan, SW Kalat-e Naderi, Joharchi \& Memariani 45455 (FUMH), *MN310918, *MN310765; Diaphanoptera lindbergii Hedge \& Wendelbo, Afghanistan, Fariab, Hedge \& al. W8336 (GB), KF924630, KF924685; Diaphanoptera stenocalycina Rech.f. \& Schiman-Czeika, Iran, Golestan, Attar \& Mehdigholi 24422 (TUH), KF924629, KF924684; Diaphanoptera transhyrcana (Preobr.) Rech.f. \& Schiman-Czeika, Turkmenistan, Great Balkan (Uly Balkan) range, Pavlenko 1773969 (H), *MN310919, *MN310766; Heterochroa desertorum Bunge, Russia, Tuviskaja ACCP, Tuva Distr., Ovjur, prope pagum Ak-Czyra Cleistogeneto-Nanphyteta Stepposa, 3 Aug 1973, Timokhina \& Daniljuk 6371 (M), MF401118, MF401171; Heterochroa violacea Fenzl, [no detail data available], JN589068, -; Kuhitangia knorringiana (Schischk.) Bondarenko 1, Uzbekistan, Nuratau mountains, Ak-Tau range, Neustrueva \& Tzvetkova 01020721 (LE), *MN310920,*MN310767; Kuhitangia knorringiana 2, Uzbekistan, northern slopes of Ak-Tau range, 22 km E of Nurata, Botschantzev \& Kamelin 01020720 (LE), *MN310921, *MN310768; Kuhitangia popovii (Preobr.) Ovcz., Turkmenistan, Köýtendag (Kugitangtau) range, Ovczinnikov \& Astanova 01020725 (LE), *MN310922, *MN310769; Saponaria kermanensis Bornm., [no detailed data available], (B: B100591988), KX184037, -; Saponaria kermanensis, [no detailed data available], (B: B100591987), KX184038, -; Saponaria makranica Rech.f., W Pakistan, Baluchistan, Makran:

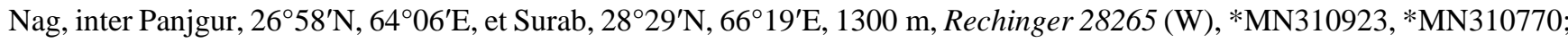
Yazdana shirkuhensis A.Pirani \& Noroozi, Iran, Yazd, Shirkuh mts, Noroozi 2827 (WU), MK637517, MK651077.

Appendix S1. The alignment file for the ITS dataset in Fasta format.

Appendix S2. The alignment file for the rps16 dataset in Fasta foramt.

\section{Figure captions}

[Figures prepated to final size: Fig. 1-3: 2 columns wide, captions below; Fig. 4: 15 cm wide, caption below.]

Fig. 1. Selected members of Acanthophyllum s.l. in natural habitats. A-C, Acanthophyllum coloratum (by Georgy Lazkov); D \& E, A. korolkowii (by Alexander Pavlenko); F-H, Allochrusa lutea (by Mohammad Mahmoodi); I \& J Diaphanoptera khorasanica (by Hamid Moazzeni \& Farshid Memariani); K, Diaphanoptera stenocalycina (by Farshid Memariani); L, Diaphanoptera transhyrcana (by Alexander Pavlenko).

Fig. 2. Majority-rule consensus tree inferred from Bayesian analysis of ITS data (left side) and rps16 data (right side). Posterior probability values are indicated above branches, ML bootstrap values below. Values below 0.5 or $50 \%$ are not shown. Colored boxes indicate taxa discussed in the present study.

Fig. 3. Putative secondary structures of the ITS1 RNA transcripts of Diaphanoptera afghanica (the ITS sequence obtained from Pirani \& al., 2014). The conserved motif of Liu \& Schardl (1994) [GGCRY-(4 to 7n)-GYGYCAAGGAA] is included in boxes.

Fig. 4. The phylogenetic positions of the 14 Acanthophyllum sections. Posterior probability values are indicated above branches, ML bootstrap values below. Values below 0.5 or $50 \%$ are not shown. The sections discussed in the present study are highlighted in bold, colored boxes. Sectional placement of species not included in boxes requires additional study. 


\section{Format table 1 in landscape format}

This article is protected by copyright. All rights reserved. 
Table 1. A list of the recognized sections of Acanthophyllum, sectional position of species included in the present study, species excluded from their original sections and not repositioned in a new section.*

\begin{tabular}{|c|c|c|c|c|c|c|c|}
\hline $\begin{array}{l}\text { Recognized } \\
\text { sections }\end{array}$ & $\begin{array}{l}\text { Sect. } \\
\text { Acanthophyllum }\end{array}$ & $\begin{array}{l}\text { Sect. } \\
\text { Allochrusa }\end{array}$ & $\begin{array}{l}\text { Sect. } \\
\text { Aphanantha }\end{array}$ & $\begin{array}{l}\text { Sect. } \\
\text { Diaphanoptera }\end{array}$ & $\begin{array}{l}\text { Sect. } \\
\text { Kuhitangia }\end{array}$ & $\begin{array}{l}\text { Sect. } \\
\text { Macrodonta }\end{array}$ & $\begin{array}{l}\text { Sect. } \\
\text { Macrostegia }\end{array}$ \\
\hline Included species & $\begin{array}{l}\text { A. acerosum } \\
\text { A. caespitosum } \\
\text { A. crassifolium } \\
\text { A. kurdicum } \\
\text { A. microcephalum } \\
\text { A. mucronatum } \\
\text { A. oppositiflorum } \\
\text { A. verticillatum }\end{array}$ & $\begin{array}{l}\text { A. bungei } \\
\text { A. lutea } \\
\text { A. persica } \\
\text { A. versicolor }\end{array}$ & A. aphananthum & $\begin{array}{l}\text { A. diaphanopterum } \\
\text { A. lindbergii } \\
\text { A. stenocalycinum } \\
\text { A. transhyrcanum }\end{array}$ & $\begin{array}{l}\text { A. knorringianum } \\
\text { A. popovii }\end{array}$ & $\begin{array}{l}\text { A. macrodon } \\
\text { A. grandiflorum } \\
\text { A. xanthoporphyranthum }\end{array}$ & $\begin{array}{l}\text { A. bracteatum } \\
\text { A. gracile } \\
\text { A. kandaharicum } \\
\text { A. leucostegium } \\
\text { A. pachystegium }\end{array}$ \\
\hline Excluded species & A. pleiostegium & & & A. ekbergii & & A. longicalyx & \\
\hline $\begin{array}{l}\text { Recognized } \\
\text { sections }\end{array}$ & $\begin{array}{l}\text { Sect. } \\
\text { Ochotonophila }\end{array}$ & $\begin{array}{l}\text { Sect. } \\
\text { Oligosperma }\end{array}$ & $\begin{array}{l}\text { Sect. } \\
\text { Paniculata }\end{array}$ & $\begin{array}{l}\text { Sect. } \\
\text { Pleiosperma }\end{array}$ & $\begin{array}{l}\text { Sect. } \\
\text { Pseudacanthophyllum }\end{array}$ & $\begin{array}{l}\text { Sect. } \\
\text { Pseudomacrostegia }\end{array}$ & $\begin{array}{l}\text { Sect. } \\
\text { Scapiflora }\end{array}$ \\
\hline Included species & A. allochrusoides & $\begin{array}{l}\text { A. aculeatum } \\
\text { A. adenophorum } \\
\text { A. andarabicum } \\
\text { A. andersenii } \\
\text { A. borsczowii } \\
\text { A. diezianum } \\
\text { A. ejtehadii } \\
\text { A. elatius } \\
\text { A. heratense } \\
\text { A. heterophyllum } \\
\text { A. kabulicum } \\
\text { A. korshinskyi } \\
\text { A. laxiusculum } \\
\text { A. lilacinum } \\
\text { A. pachystegium } \\
\text { A. pulchrum } \\
\text { A. pungens }\end{array}$ & $\begin{array}{l}\text { A. gypsophiloides } \\
\text { A. paniculatum }\end{array}$ & $\begin{array}{l}\text { A. crassinodum } \\
\text { A. glandulosum } \\
\text { A. schugnanicum } \\
\text { A. spinosum }\end{array}$ & $\begin{array}{l}\text { A. laxiflorum } \\
\text { A. raphiophyllum } \\
\text { A. stewartii }\end{array}$ & $\begin{array}{l}\text { A. coloratum } \\
\text { A. korolkowii } \\
\text { A. sarawschanicum } \\
\text { A. tadshikistanicum }\end{array}$ & $\begin{array}{l}\text { A. anisocladum } \\
\text { A. scapiflorum }\end{array}$ \\
\hline
\end{tabular}


A. speciosum

A. squarrosum

A. stocksianum

A. subglabrum

A. yasamin-nassehiae

Excluded species

A. caespitosum

A. sordidum

* Acanthophyllum cerastioides, A. hernarioides, A. honigbergeri, A. kermanense, A. makranicum, and A. myrianthum have been transferred to Acanthophyllum which their sectional position is not resolved. 

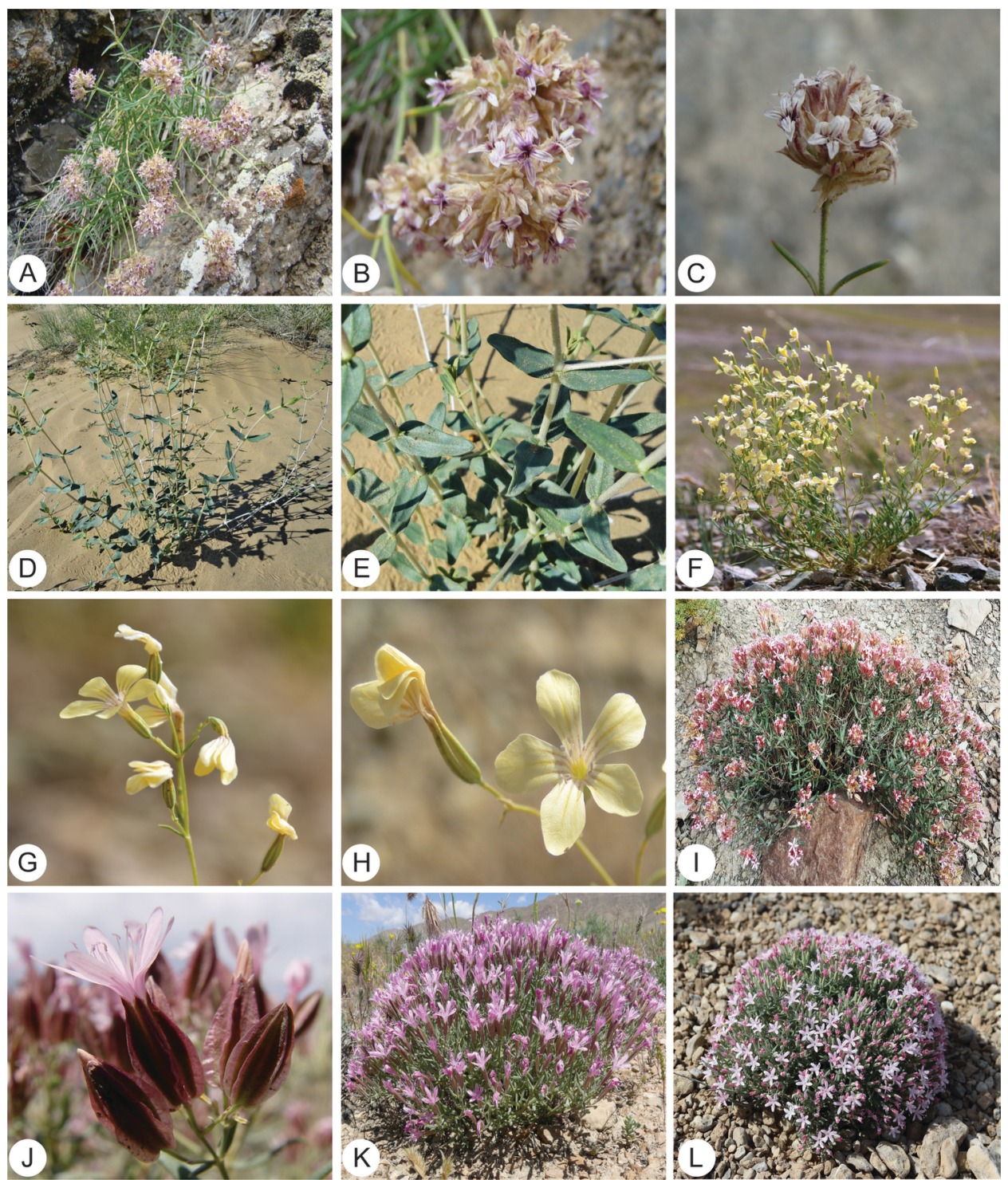

TAX_12241_Figure_1_CMYK_LZW.tif

This article is protected by copyright. All rights reserved. 
0.86 Acanthophyllum subglabrum

Acanthophyllum heterophyllum

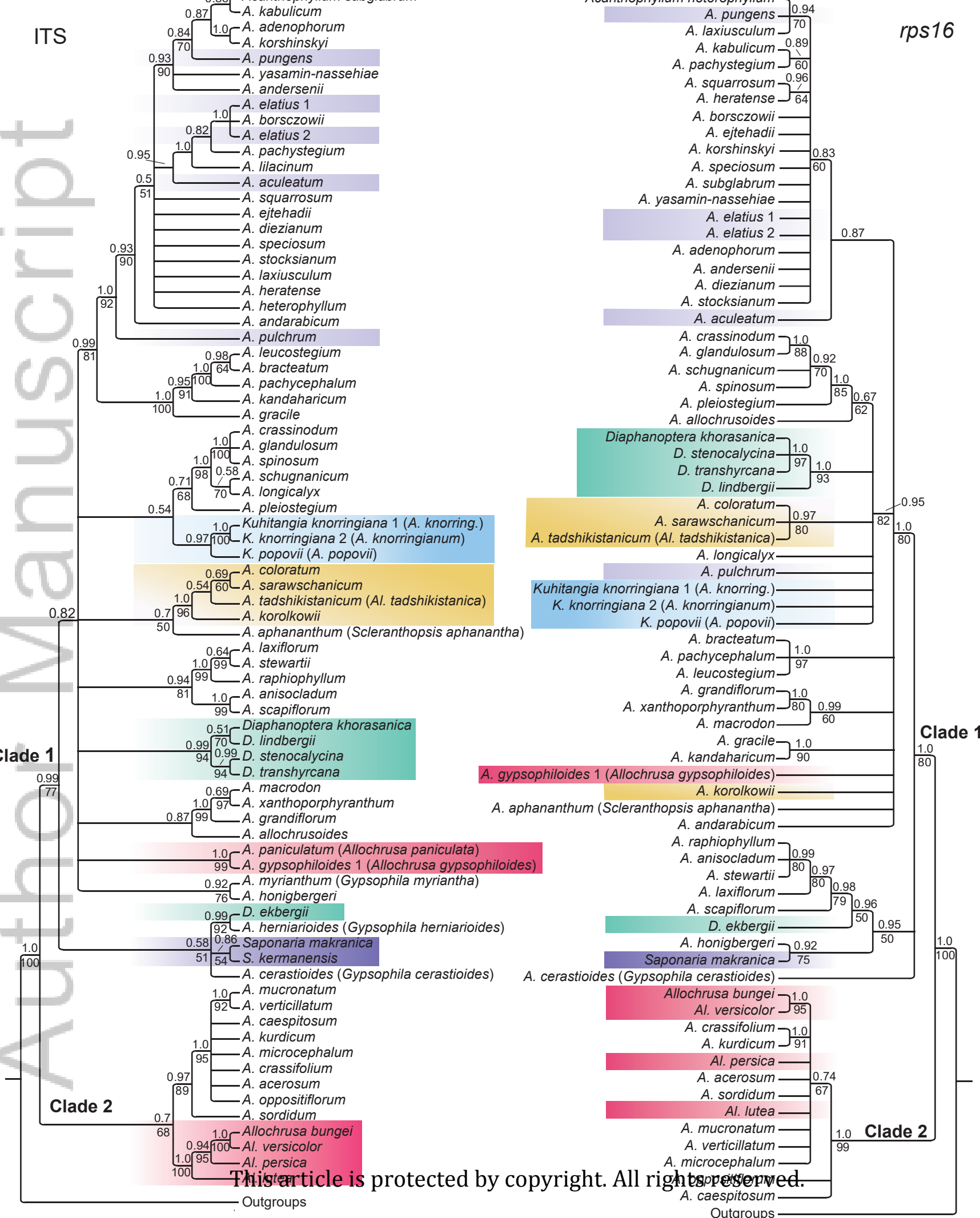


Probability $\geq 99 \%$

$99 \%>$ Probability $\geq 95 \%$

$95 \%>$ Probability $\geq 90 \%$

$90 \%>$ Probability $\geq 80 \%$

$50 \%>$ Probability

ENERGY $=-47.1$ Diaphanoptera afghanica

This article 9 s protected by copyright. All rights reserved. 
Sect. Oligosperma

Sect. Macrostegia

Sect. Pleiosperma

Sect. Kuhitangia

Sect. Pseudomacrostegia

Sect. Aphanantha

Sect. Pseudacanthophyllum

Sect. Scapiflora

Sect. Diaphanoptera

Sect. Macrodonta

Sect. Ochotonophila

Sect. Paniculata

Sect. Acanthophyllum

Clade 2 A. caespitosum

A. macrodon

0.8799 A. xanthoporphyranthum A. grandiflorum

A. allochrusoides

1.0 - A. paniculatum

99 A. gypsophiloides

92 A. myrianthum

$0.99-A$. ekbergii

${ }_{92}-A$. herniarioides

$0.58 \quad 0.86$ - A. makranicum

51 - 54 - kermanense

- A. cerastioides

100 A. lutea 